\title{
The Attribution of Responsibility and Modes of Liability in International Criminal Law
}

\begin{abstract}
In 2012, James Stewart published an article in this journal. The piece - 'The End of "Modes of Liability" for International Crimes' - argued for the abolition of accomplice liability in international criminal law and the adoption of a unitary model of participation in crime. This article argues that Stewart's proposal is flawed. As a matter of moral responsibility, the distinction between principals and accomplices follows from the recognition of individuals as moral agents. Turning to ordinary criminal responsibility, neither practical benefits nor expressive benefits nor the mitigating effects of the distinctive institution of criminal sentencing justifies the abolition of the distinction between principals and accomplices. Moreover, despite the collective nature of many international crimes, international criminal law ought to strive to accurately differentiate, in the attribution of responsibility, among participants. Only a differentiated model of participation can accurately and defensibly capture the different ways that individuals contribute to wrongdoing.
\end{abstract}

Keywords - complicity / attribution / modes of liability / sentencing / perpetration

\section{Introduction}

In 2012, James Stewart published an article in this journal. ${ }^{1}$ The piece - 'The End of "Modes of Liability" for International Crimes' drew a great deal of attention from the academic community of international criminal lawyers: discussion on blogs, responses in subsequent scholarship, ${ }^{2}$ a symposium on Opinio Juris. ${ }^{3}$ In brief, its argument was that orthodox modes of responsibility in international criminal law should collapse into a single concept of perpetration. ${ }^{4}$ On this account, all those who contribute to an international crime with the requisite mental element are perpetrators. There are no accomplices.

In the initial responses, as well as in subsequent academic engagement, one aspect of the piece went unnoticed: the author's acknowledgments. Of course, an author's acknowledgments generally do not provoke critical commentary. At first glance, Stewart's acknowledgments appear to be run-of-the-mill:

\footnotetext{
${ }^{1}$ J. Stewart, 'The End of "Modes of Liability" for International Crimes', (2012) 25 LJIL 165.

${ }^{2}$ See e.g. G. Werle and B. Burghardt, 'Establishing Degrees of Responsibility: Modes of Participation in Article 25 of the ICC Statute', in E. Van Sliedregt and S. Vasiliev (eds.), Pluralism in International Law (2014), 301; M. Jackson, Complicity in International Law (2015), at 18-20.

${ }^{3}$ D. Robinson, 'LJIL Symposium: Darryl Robinson comments on James Stewart's "End of Modes of Liability"', Opinio Juris, 21 March 2012 available at http://opiniojuris.org/2012/03/21/ljil-robinson-comments-on-stewart/; T. Weigend, 'LJIL Symposium: Thomas Weigend comments on James Stewart's "The 'End of Modes of Liability for International Crimes"', Opinio Juris, 22 March 2012, available at http://opiniojuris.org/2012/03/22/1ji1-weigendcomments/; J. Ohlin, 'LJIL Symposium: Names, Labels, and Roses', Opinio Juris, 23 March 2012 available at http://opiniojuris.org/2012/03/23/ljil-names-labels-and-roses/.

${ }^{4}$ Stewart, supra note 1 , at 169 .
} 
...This project was partly undertaken while a Visiting Fellow at Oxford's Centre for Criminology. My kind thanks to Larry Alexander, José Alvarez, Nicole Barrett, Roger Clark, Markus Dubber, Thomas Weigend, Kevin Jon Heller, Johannes Keiler, Darryl Robinson, Elies van Sliedregt, Stefano Manacorda, Jenny Martinez, Frédéric Mégret, Jens Ohlin, Bettina Weißer, and Harmen van der Wilt for their very helpful criticisms. Errors are mine alone. ${ }^{5}$

On reflection, they demand a little more attention, for they raise an interesting question about the boundaries of authorship. The Centre for Criminology at the University of Oxford - and its Director and Fellows - presumably provided some institutional support for the project, perhaps an office, library resources, and access to a community of scholars. One would assume that some of the scholars listed commented on drafts, offered critical insight, or referred Stewart to longforgotten cases. Perhaps the involvement of others was limited to encouragement. It seems fair to conclude that most of those named made some contribution to the article.

At the same time, however, it is certain that Stewart, and Stewart alone, claims authorship of the piece. A quick review of the research profiles of other scholars named in the acknowledgments reveals this to be true. There is no chance that Kevin Jon Heller or Jenny Martinez or Elies van Sliedregt would claim to have written what they did not write.

On this basis, it seems clear that within the community of legal scholars, orthodox modes of responsibility have not collapsed into principalship. Some people write articles; some provide funding; others offer encouragement; others give critical feedback. In some cases, an article may be written together - co-authorship is common. On more hierarchical campuses, some of these co-author relationships might look more like 'indirect authorship', with the more senior colleague doing most of the thinking and the more junior doing most of the work. ${ }^{6}$ Nonetheless, the boundaries of authorship are generally settled.

This analogy, frivolous as it might seem, tips us off to a very basic point in understanding the idea of responsibility. That none of Stewart's helpers claim authorship of his article is not simply a matter of collegiality. Instead, it is driven by a principle at the core of an orthodox and intuitive account of moral responsibility: we are each responsible for our own intentional acts. ${ }^{7}$ Underpinning this basic principle is an appreciation of the moral agency of the individual subject. ${ }^{8}$

For this reason, Stewart is left with a dilemma. On the one hand, he wishes to ascribe to those who assist or encourage international crimes the crimes of their principals. On the other hand, he is happy to claim authorship of his article to the exclusion of those who assisted and encouraged him. At first glance, at least, one might wonder if one of these claims must give way.

\footnotetext{
${ }^{5}$ Ibid., at 165 .

${ }^{6}$ Cf. C. Roxin, Täterschaft und Tatherrschaft (1963).

${ }^{7}$ J. Gardner, 'Complicity and Causality', (2007) 1 Criminal Law and Philosophy 127, at 132. See further Section 3.1 below.

${ }^{8}$ C. Kutz, Complicity: Ethics and Law for a Collective Age (2000), at 3-4.
} 
In this article, I suggest that there are three possible ways to escape the dilemma; that is, three rebuttals to this purported inconsistency. First, it may be that the orthodox and intuitive ascription to individuals of responsibility for their own intentional actions applies with less force when the action concerned is wrongful. In other words, though Stewart is responsible for his own article (and any other virtuous or morally-neutral action), the situation may be different when we are dealing with moral wrongdoing. Second, and assuming the first defense fails, it may be that although individuals are responsible for their own intentional acts as a matter of moral responsibility, the law should take a different approach. Evidential or other policy concerns, perhaps, may demand that the criminal law treats those who assist or encourage crime as principal wrongdoers. Alternatively, the distinctive institution of criminal sentencing might mean that the principled difficulties attached to convicting an individual of another's acts do not matter. Third, it may be that whether or not criminal law generally is justified in collapsing principal and accomplice liability, international criminal law specifically ought to do so. This might be for similar policy reasons or may turn on claims about the collective nature of international crimes.

I argue that none of these three defenses succeeds. Section 2 sets out Stewart's argument for the elimination of complicity from international criminal law. Section 3 considers each of the three arguments that might allow an escape from the dilemma. The rejection of these arguments is underpinned by an appreciation of the distinctive significance of complicit conduct in morality and law. In the process of examining the dilemma, the case for a properly differentiated system of responsibility for international crimes becomes clear. ${ }^{9}$

\section{2. 'The End of Modes of Liability': Stewart's Account}

International criminal law has long inculpated a range of participants in international crimes. Article 6 of the Charter of the International Military Tribunal at Nuremberg speaks of leaders, organizers, instigators, and accomplices. ${ }^{10}$ The statutes of the ad hoc tribunals provide for the responsibility of planners, instigators, orderers, perpetrators, aiders and abettors. ${ }^{11}$ In the Rome Statute, we find individual, joint, and indirect perpetration; ordering, soliciting, and inducing; aiding, abetting, and otherwise assisting; and a not entirely clear reference to various contributions to group crime. ${ }^{12}$ There are evidently many different ways to participate in international crimes.

A great deal of doctrinal and critical attention has focused on modes of liability that inculpate military or political leaders - joint criminal enterprise, command responsibility, perpetration-bymeans, and perpetration through an organization. Stewart argues that the development of these

\footnotetext{
${ }^{9}$ See E. van Sliedregt, Individual Criminal Responsibility in International Law (2012), at 70 describing such an approach as a 'pure' differentiated model of responsibility.

${ }^{10}$ Art. 6, Charter of the International Military Tribunal (Nuremberg) annexed to Agreement for the Prosecution and Punishment of the Major War Criminals of the European Axis (signed in London, 8 August 1945) 82 UNTS 279. See also Art. 5(c), Charter of the International Military Tribunal for the Far East (19 January 1946, amended 25 April 1946) TIAS No 1589.

${ }^{11}$ Art. 7, Statute of the International Criminal Tribunal for the Former Yugoslavia adopted by UNSC Res 827 (25 May 1993) UN Doc S/RES/827; Art. 6, Statute of the International Criminal Tribunal for Rwanda adopted by UNSC Res 955 (8 November 1994) UN Doc S/RES/955.

12 Art. 25, Rome Statute of the International Criminal Court (adopted 17 July 1998, entered into force 1 July 2002) 2187 UNTS 90.
} 
doctrines has been driven by what he calls the Hitler-as-accomplice problem - the idea 'that the application of everyday rules of criminal attribution leads to Hitler's conviction as an accomplice to the Holocaust. ${ }^{13}$ Such a conviction, in Stewart's account, would be simply indefensible. ${ }^{14}$

At the same time, however, these broad inculpatory doctrines have been subject to stinging critique by scholars. For instance, Damaška has argued that command responsibility pays insufficient attention to the commander's own personal culpability ${ }^{15}$ Ohlin has argued that joint criminal enterprise is theoretically flawed in its imposition of equal responsibility on participants who make vastly different contributions. ${ }^{16}$ Drawing on these and other works of a comparable bent, Stewart argues that accomplice liability in international criminal law has escaped similar critical scrutiny, even though it is susceptible to similar challenge. ${ }^{17}$ This, then, is a crucial part of his argument for the adoption of a unitary model of perpetration - to show that complicity, as currently understood in international criminal law, does not meet the requirements of theoretical justification.

Stewart contends that accomplice liability falls short of two necessary conditions of theoretical justification: (i) the existence of congruence between the mental element of the crime and the mental element required of the accomplice, and (ii) the presence of a causal connection between the accomplice's acts and the harm denoted by the crime. ${ }^{18}$ In respect of the mental element, Stewart argues that any fixed standard of fault for accomplices is indefensible. ${ }^{19}$ Where the standard for the principal crime is intent and the standard for accomplices is knowledge or recklessness, complicity amplifies the responsibility of the accomplice in violation of the principle of culpability. Where the standard for the principal crime is knowledge or less and the standard for accomplices is purpose, complicity absolves putative accomplices in situations where they ought to be responsible. ${ }^{20}$

Moving on to the physical element of complicity, Stewart recognizes international criminal law doctrine's repeated assertions that complicity requires proof of neither a cause-effect nor condition-precedent relationship. ${ }^{21}$ This he takes to indicate that accomplice liability in international criminal law is acausal, which threatens the fundamental principal of personal culpability. ${ }^{22}$ However, the same doctrine indicates that accomplices must have a substantial effect on the principal's crime. ${ }^{23}$ Drawing on Gardner's argument that 'there is no way of

\footnotetext{
${ }^{13}$ Stewart, supra note 1 , at 167.

${ }^{14} \mathrm{Ibid}$.

${ }^{15}$ M. Damaška, 'The Shadow Side of Command Responsibility', (2001) 49 American Journal of Comparative Law 455 , at 456.

${ }^{16}$ J. Ohlin, 'Three Conceptual Problems with the Doctrine of Joint Criminal Enterprise', (2007) 5 JICJ 69. See also

D. Robinson, 'The Identity Crisis of International Criminal Law', (2008) 21 LJIL 925.

${ }^{17}$ Stewart, supra note 1, at 168 .

${ }^{18}$ Ibid., at 185 .

${ }^{19}$ Ibid., at 191-99

${ }^{20}$ Ibid., at 197.

${ }^{21}$ Ibid., at 199.

${ }^{22}$ Ibid., at 199-200. See e.g. Prosecutor v. Blaškić, Judgement, Case No. IT-95-14-A, Appeals Chamber, 29 July 2004, at para 48.

${ }^{23}$ See e.g. Prosecutor v. Simić, Judgement, Case No. IT-95-9-A, Appeals Chamber, 28 November 2006, at para 85; Prosecutor v. Mrkšić and Šljivančanin, Judgement, Case No. IT-95-13/1-A, Appeals Chamber, 5 May 2009

('Mrkšić and Šljivančanin appeal judgment'), at para 81.
} 
contributing to any result, directly or indirectly, except causally', Stewart suggests that it must be the case that accomplices causally contribute to the principal crime. ${ }^{24}$ If they causally contribute to the principal crime and are marked by the same fault element of the principal offender, why should we not simply treat accomplices as a subset of perpetrators? ${ }^{25}$

This idea drives his argument that all modes of liability can be collapsed into a single unitary model of perpetration. Such a model would hold responsible as a principal any participant who 'made a substantial causal contribution to a prohibited harm while harbouring the mental element necessary to make him responsible for that crime. ${ }^{26}$ As to the abolition of a distinction between principals and accomplices, Stewart suggests both that (i) there is no moral difference between the two, and (ii) even if there were a moral difference, there is no reason that the accomplice's distinct contribution cannot be accounted for at sentencing, rather than in the attribution of responsibility. ${ }^{27}$ Moreover, given the particularities of international criminal justice, there would be expressive and practical benefits to replacing a differentiated model with a unitary one. ${ }^{28}$

\section{The Dilemma}

At this point, we can return to the dilemma: Stewart would deny that those who assisted and encouraged his writing of the article are responsible for writing it while at the same time ascribing principal responsibility to those who assist or encourage others to commit international crimes. There are three possible ways out of the dilemma. The first distinguishes morally virtuous and morally wrongful conduct. The second distinguishes moral responsibility and criminal responsibility. The third distinguishes criminal responsibility generally and international criminal responsibility specifically. None of these succeeds.

\subsection{Moral Responsibility}

The first possibility is to argue that as a matter of moral responsibility, there might be reasons to treat virtuous or morally neutral acts like writing an article differently from wrongful acts like killing a civilian in war. This is would explain why we recognize the range of different forms of participation in the attribution of responsibility for the article but need not do the same in ascribing responsibility for international crimes.

Such an argument is implausible for a simple reason. Whatever arguments there are for attributing to people responsibility for their own virtuous acts are present and probably magnified when we are talking about moral responsibility for wrongdoing. ${ }^{29}$ This is because judgements as to moral responsibility for wrongdoing entail blame. ${ }^{30}$ Although it is not right to fail to attribute responsibility to individuals for their virtuous actions - or those actions deserving

\footnotetext{
${ }^{24}$ Stewart, supra note 1, at 200. See also Gardner, 'Moore on Complicity and Causality' (2008) 156 University of Pennsylvania Law Review PENNumbra 432.

${ }^{25}$ Stewart, supra note 1, at 204.

${ }^{26}$ Ibid., at 207.

${ }^{27}$ Ibid., at 207-8.

${ }^{28}$ Ibid., at 213-218.

${ }^{29}$ As the proverb goes: 'success has many fathers, but failure is an orphan.'

${ }^{30}$ See generally P. Strawson, Freedom and Resentment and Other Essays (1974); T. Scanlon, Moral Dimensions: Permissibility, Meaning, Blame (2008).
} 
of praise or gratitude - it seems a more serious thing to incorrectly attribute responsibility for wrongdoing - and thus blame - to one who has not done the wrong in question. ${ }^{31}$

Whether the action is virtuous or wrongful, the reason we should attribute responsibility to individuals for their own intentional acts and not the acts of others lies in the recognition of people as moral agents capable of choice. ${ }^{32}$ This may seem an obvious point, but it is important. This basic point manifests in the criminal law in the principle of culpability. ${ }^{33}$ One element of the principle of culpability demands that, in the absence of countervailing justification, individuals are only held criminally responsible for their own conduct and its consequences. ${ }^{34}$

It should be emphasized, however, that the principle of culpability does not lead to an atomized conception of responsibility. There is no doubt that our own acts often have effects on the acts of others. ${ }^{35}$ This point is underlined in ordinary and legal descriptions of participation in wrongdoing - wrongs may be commanded, ordered, or procured; induced, instigated, or encouraged; assisted, facilitated, or abetted; tolerated, sanctioned, or permitted. ${ }^{36}$ A coherent account of responsibility must consider these many forms of participation.

At the same time, a coherent account of responsibility must come to terms with the many ways that we act together. The philosophical literature on shared and collective responsibility is rich; central questions include the moral responsibility of the group qua group and the distributional possibilities of ascribing responsibility for the group's actions to its individual members. ${ }^{37}$ In law, state responsibility in international law and corporate responsibility in municipal law might be seen as partial responses to the first question; various forms of joint commission in the criminal law might be seen as responding to the second. ${ }^{38}$

In any event, the key question is how responsibility is allocated among the various participants in wrongdoing. For present purposes, the focus remains on the archetypal act of complicity - the provision of aid to another actor (or actors) that facilitates her wrongdoing. ${ }^{39}$ For common lawyers, steeped in the received wisdom that accomplice liability necessarily involves liability for the acts of another, it might be hard to imagine any other way of understanding the moral

\footnotetext{
${ }^{31}$ For further discussion of the relationship between different kinds of reactive attitudes and responsibility, see R. Wallace, Responsibility and the Moral Sentiments (1994).

${ }^{32}$ Gardner, supra note 7, at 132. See also Kutz, supra note 8, at 3-4.

${ }^{33}$ See M. Kremnitzer and T. Hörnle, 'Human Dignity and the Principle of Culpability', (2011) 44 Israel Law Review 115.

${ }^{34}$ See Robinson, supra note 16. See also Damaška, supra note 15, at 464.

${ }^{35}$ See generally Kutz, supra note 8.

${ }^{36}$ See generally Jackson, supra note 2, at 10-11.

${ }^{37}$ See e.g. J. Feinberg, 'Collective Responsibility', (1968) 65 Journal of Philosophy 674; J. Searle, 'Collective Intentions and Actions' in P. Cohen, J. Morgan, and M. Pollack (eds.), Intentions in Communication (1990), 401; M. Gilbert, 'Shared Intention and Personal Intention', (2009) 144 Philosophical Studies 167; M. Bratman, Shared Agency: A Planning Theory of Acting Together (2014).

${ }^{38}$ See generally H. Kelsen, 'Collective and Individual Responsibility in International Law with Particular Regard to the Punishment of War Criminals', (1943) 31 California Law Review 530; P. Pettit, 'Responsibility Incorporated', (2007) 117 Ethics 171.

${ }^{39}$ S. Kadish, 'Complicity, Cause and Blame', (1985) 73 California Law Review 323, at 342
} 
responsibility of the accomplice. ${ }^{40}$ Though there is surely a good historical explanation for how the law evolved in this way, there is no reason that this ought to be so. In fact, as a matter of moral responsibility, the fundamental principle that we are each responsible for our own intentional acts is as applicable to accomplices as it is in any other situation. In this regard, Gardner argues that:

...the distinction between principals and accomplices is embedded in the structure of rational agency. As rational beings we cannot live without it. I am responsible for what I do, and you are responsible for what you do. But on any credible view I need to give attention, in what I do, to what you will do in consequence. And you need to give attention, in what you do, to what I will do in consequence. In that sense, there are two parts of morality. There is what I should do simpliciter, and then there is what I should do by way of contribution to what you do. If I fail in the first I am a principal. If I fail in the second I am an accomplice. ${ }^{41}$

To put it almost tautologically, what an accomplice is responsible for is what she has done. In the central case, what she has done is make a causal contribution to the principal's wrong. ${ }^{42}$

This basic point is equally applicable in collective contexts. No doubt, there are instances where participants truly act jointly and are collectively and individually responsible for the actions of other members of the group - common examples are business partnerships, joint authorship, and sports teams. ${ }^{43}$ But far more common will be instances where the bonds between collective actors are more diffuse, and where the actions and intentions of the members of such a diffusely associated group vary greatly. ${ }^{44}$ Moreover, there will be participants who contribute to the wrong from outside of any plausibly constructed group. ${ }^{45}$

In these instances, moral responsibility tracks the participants' individual contributions to the wrong. ${ }^{46}$ Giving the example of a bank robbery where $\mathrm{C}$ and $\mathrm{D}$ plan a robbery, receive encouragement from A, weapons from B, transport from the scene from E, assistance after the robbery from $\mathrm{F}$, and toleration from $\mathrm{G}$, Feinberg explains:

We can [in morality] afford to have stricter standards of culpability than the lawyers since no formal punishment will follow as a result of our verdicts, and we don't have to worry about procedural complexities.

\footnotetext{
${ }^{40}$ See 18 USC $§ 2$ (1994) (USA); Accessories and Abettors Act 1861, as amended by Schedule 12 to the Criminal Law Act 1977, s 8.

${ }^{41}$ Gardner, supra note 7, at 132.

${ }^{42}$ K.J.M. Smith, A Modern Treatise on the Law of Criminal Complicity (1991); Gardner, supra note 7, at 128. Cf. C. Kutz, 'Causeless Complicity' (2007) 1 Criminal Law and Philosophy 289 for a discussion of causal indeterminacy in the relations between the accomplice and principal.

${ }^{43}$ Feinberg, supra note 37 , at 677.

${ }^{44}$ See generally J. Ohlin, 'Group Think: The Law of Conspiracy and Collective Reason', (2007) 98 Journal of Criminal Law and Criminology 147.

${ }^{45}$ Think, perhaps, of a sports team's physiotherapist, or bus-driver, or kit-man.

${ }^{46}$ See T. Isaacs, Moral Responsibility in Collective Contexts (2011), 102-129; G. Fletcher, Romantics at War: Glory and Guilt in the Age of Terrorism (2002), 161-163.
} 
Part of the problem of determining degrees of responsibility of individuals in joint undertakings, where the responsibility is not vicarious, is that of assessing the extent of each individual's contribution to the undertaking. This involves assessment of various incommensurable dimensions of contribution - degrees of initiative, difficulty or causal crucialness of assigned subtasks, degrees of authority, percentage of derived profit, and so on. Although these matters cannot be settled in any mathematical way, rough and ready answers suggest themselves to common sense, and the legal categories of complicity have proved quite workable. $^{47}$

In the context of mass atrocity, the question is both who is responsible and how are they responsible? Indeed, the sheer range of participants' contributions - from the intellectual authors of the crime to ordinary citizens who voted them into office, from the general who gives the order to a private who stands guard outside the prison camp - points to a graded understanding of moral responsibility. To use Stewart's example, though Eichmann and ordinary Germans bear responsibility for the Holocaust, it is implausible to consider them equally responsible. ${ }^{48}$

So to return to our dilemma, just as a principal wrongdoer is responsible for her wrong and her accomplices are responsible for their contribution to the principal wrong, Stewart is responsible for writing his article and his helpers are responsible for helping him to write the article. He is not responsible for their assistance and they are not responsible for his article. Notice that each gets credit for what he or she has done: Stewart as the author, the Centre for Criminology and its Directors and Fellows for providing institutional support, and his commenters for their assistance.

\subsection{Criminal Responsibility}

That principals are morally responsible for their wrongs and accomplices are morally responsible for their contribution to the principal's wrong does not necessarily condemn Stewart's elimination of complicity and adoption of a unitary model of participation in crime. Although we might assume that there ought to be a close relationship between moral and criminal responsibility, there may be instances where the two justifiably diverge. ${ }^{49}$ If this is true, the question is whether there are good reasons that a legal system ought to consider all of those who contribute to crime as principals, even if that is inconsistent with their respective moral responsibility.

At the outset, a simple point is worth reiterating. It does no favours to the argument for abandoning complicity and adopting a unitary model of perpetration to point out that accomplice liability in the common law ends up convicting the accomplice of the principal's crime. It is true that the doctrinal differentiation among participants in the common law is not matched by differentiation in the attribution of responsibility. ${ }^{50}$ But the common law position is itself open to

\footnotetext{
${ }^{47}$ Feinberg, supra note 37 , at 685.

${ }^{48}$ See generally K. Jaspers, The Question of German Guilt (trans. by E. Ashton), (2001).

${ }^{49}$ For further discussion, see P. Cane, Responsibility in Law and Morality (2002); M. Moore, Causation and Responsibility (2009); A. Duff, 'Legal and Moral Responsibility', (2009) 4 Philosophy Compass 978.

${ }^{50}$ See 18 USC $\S 2$; Accessories and Abettors Act, s 8. On doctrinal differentiation, differentiation in the attribution of responsibility, and differentiation in sentencing, see Jackson, supra note 2, at 22-6.
} 
challenge and cannot be used to justify a similarly unjustifiable model in international criminal law.

In any case, there are three possible arguments for the elimination of complicity from law, or at least two for the elimination of complicity and one that suggests that the elimination does not matter. Stewart makes all three. The first concerns the evidential and practical advantages of a unitary model. The second concerns the expressive possibilities of the criminal law. And the third proposes that we need not distinguish between principals and accomplices in the attribution of responsibility because any morally significant differences between them can be captured at sentencing.

\subsubsection{Practical and Evidential Advantages}

There is no doubt that international criminal law has undergone a rapid evolution over the last two decades. There remain a number of doctrinal controversies in the definitions of substantive crimes and modes of liability. Different international courts have provided different answers to the same questions. Modes of liability have become technical; trials are expensive; and processes are far removed from the sites of violence. ${ }^{51}$

Stewart's argument is that adopting a unitary model of perpetration would simplify proceedings, free up resources to prosecute more offenders, and minimize the selectivity of trials. ${ }^{52}$ Leaving aside the doubt that the expense and time difficulties that plague international criminal justice are predominantly or even moderately caused by complexities around modes of liability, no evidence is put forward that domestic systems that follow a unitary model are relatively free of doctrinal complexities. It is one thing to say that all a unitary model requires is substantial causal contribution to the harm, it is quite another to assume that what that means in the varied instances of potential criminal responsibility will be straightforward.

In addition, on Stewart's own account, different forms of participation should be taken into account at sentencing. ${ }^{53}$ This claim is assessed in more detail below. At this point, it suffices to say that this concession undermines the argument that a unitary model will have significant practical benefits in cost and time. ${ }^{54}$ Even if substantial causal contribution is the standard that governs the attribution of responsibility, what the participant actually did will determine the extent of his sentence. Given that complicity captures a distinct way of contributing to wrongdoing and that the language of complicity is deeply embedded in our everyday practices, questions of complicity will re-emerge at sentencing. Over time, certain principles will likely (and ought to) come to govern the sentencing of different kinds of participants. Defendants will argue that they fall into one category or the other. Appeals will go forward. Disagreements will arise. $^{55}$

So the idea that a unitary model would have practical benefits is insufficiently defended. However, even assuming there would be some small practical benefit, why should this small

\footnotetext{
${ }^{51}$ Stewart, supra note 1 , at 213-18.

52 Ibid.

${ }^{53}$ Stewart, supra note 1 , at 208.

${ }^{54}$ Weigend, supra note 3.

${ }^{55}$ This is leaving aside the legality concerns that accompany broad sentencing discretion. See Ohlin, supra note 3.
} 
practical benefit justify a significant departure from the fundamental principle of culpability the conviction of individuals for wrongs that they did not commit. To scholars who have driven what might be called the liberal reformation of international criminal law scholarship, such a sacrifice of fundamental principle should be anathema. ${ }^{56}$

\subsubsection{Expressive Benefits}

A second argument that we ought to eliminate complicity from the criminal law turns on the supposed expressive benefits of doing so. It is certainly the case that holding accomplices responsible for the principal's crime connects them more directly to the harm to which they contribute. This might be seen to heighten the condemnatory aspect of criminal responsibility for central cases of complicity.

Beyond this basic point, the argument that eliminating complicity would have expressive benefits is not convincing. On first glance, the elimination of complicity would seem to violate the principle of fair labelling in criminal law. ${ }^{57}$ The principle of fair labelling demands that wrongdoing is labelled accurately and with a sufficient degree of specificity to distinguish lawbreaking of a different kind or gravity. ${ }^{58}$ It is not only a matter of fairness to wrongdoers but also ensures that law, in its communicative function, accurately conveys to the public what the wrongdoer did. ${ }^{59}$

Stewart denies that a distinction between principal and accomplice liability serves the principle of fair labelling for two reasons. The first is that in current practice international criminal courts do not generally mention the mode of liability in the disposition of their judgments. ${ }^{60}$ Even if this is true as a matter of practice, it is a strange argument at the level of principle for the straightforward reason that we can simply argue that in contrast to their current practice, international criminal courts ought to mention the mode of liability in the disposition.

Stewart's second reason for denying the applicability of the principle of fair labelling is that modes of liability, in their complexity, do not themselves convey any readily understandable meaning to victims, perpetrators, and wider society. He argues that there is a risk 'that the meaning of increasingly abstract legal terms used to describe modes of liability seems esoteric to ordinary citizens, who no longer understand the terminology or its moral implications. ${ }^{, 61}$

While this claim is plausible with respect to, say, indirect perpetration, it is implausible in respect of central cases of complicity. The idea of helping someone else to do wrong is widely and straightforwardly understood. Although accomplice liability has some fair labelling concerns as to the specificity of the description, ${ }^{62}$ aiding and abetting is not really a piece of legalese that the layman is incapable of deciphering.

\footnotetext{
${ }^{56}$ See Damaška, supra note 15; Robinson, supra note 16; Ohlin, supra note 16.

${ }^{57}$ For an in-depth discussion, see J. Chalmers and F. Leverick, 'Fair Labelling in Criminal Law' (2008) 71 Modern Law Review 217.

${ }^{58}$ A. Ashworth and J. Horder, Principles of Criminal Law (2013) 77-79.

${ }^{59}$ Ibid. See also V. Tadros, 'Fair Labelling and Social Solidarity' in L. Zedner and J. Roberts (eds.), Principles and Values in Criminal Law and Criminal Justice (2012).

${ }^{60}$ Stewart, supra note 1 , at 211.

${ }^{61}$ Ibid., at 212.

${ }^{62}$ See D. Husak, 'Abetting a Crime', (2014) 33 Criminal Law and Philosophy 41, at 61.
} 
Beyond denying the fair labelling benefits of accomplice liability, Stewart goes on to argue that the unitary model might actually have increased expressive benefits. To reiterate, under his unitary theory anyone who makes a substantial causal contribution to the principal crime with the appropriate intention is guilty of the principal crime. But the idea that the label of 'making a substantial causal contribution' to the principal crime conveys anything widely understandable is doubtful.

Anticipating this objection, Stewart suggests two alternatives. First, he proposes that the 'judgment could append a single plain language explanation' of the defendant's contribution after the disposition. ${ }^{63}$ This seems a good idea, even if more complex cases might require more than a few sentences. But if it is a good idea, why could such a plain-language explanation not also follow the disposition in a system using a differentiated model of perpetration? ${ }^{64}$

Second, Stewart suggests that instead of the mode of liability and crime playing the role of accurately labelling the defendants, the judgment itself might carry some of the load. ${ }^{65}$ This is a strange argument. At the level of principle, the disposition of the court is more than just the conclusion to a description of events as they occurred; rather, it is a verdictive speech act, in this case an official judgement as to criminal responsibility. ${ }^{66}$ As such, it imposes on the accused the status of criminality, and it must do so accurately. ${ }^{67}$ On a practical level, it is extremely unlikely that the wider public is going to read the judgments of international criminal tribunals. We are ordinarily dealing with hundreds, if not thousands, of pages, translations are slow in forthcoming, and the content is often a little dry.

For these reasons, the expressive benefits of a unitary model of responsibility are more illusory than real. ${ }^{68}$ It might a good idea to append a plain-language explanation of the basis of responsibility to the judgment, but there is no reason that this would only be possible under the unitary model. More importantly, a properly differentiated model of responsibility accurately labels participants in the attribution of responsibility and conveys to the wider public the general nature of their wrongdoing.

\subsubsection{Sentencing}

If the first two arguments for the elimination of complicity from legal responsibility turn on the purported practical and expressive benefits of doing so, the third turns on the particular institution of criminal sentencing. In addition to the finding of responsibility denoted by the verdict, criminal proceedings impose punishment on the wrongdoer. The argument, then, is that variations in culpability among participants in crime can be accounted for at the sentencing stage. $^{69}$

\footnotetext{
${ }^{63}$ Stewart, supra note 1, at 212.

${ }^{64}$ Robinson, supra note 3.

${ }^{65}$ Ibid., at 212-13.

${ }^{66}$ J.L. Austin, How to Do Things with Words (1962) 150.

${ }^{67}$ See generally W. Alston, Illocutionary Acts and Sentence Meaning (2000) 88-89.

${ }^{68}$ See Ohlin, supra note 3.

${ }^{69}$ Stewart, supra note 1, at 207.
} 
One way to respond to this argument is by way of a simple reductio ad absurdum. Ohlin asks whether Stewart would be happy to abolish all substantive crimes in international criminal law and replace them with a single crime of atrocity. ${ }^{70}$ Any morally significant differences among different participants (or, to use Stewart's phrase, 'substantial causal contributors') could be expressed at sentencing. Domestically, we could abolish all of criminal law and replace it with a single crime of felony. ${ }^{71}$ This would obviously be absurd - some participants' responsibility would be radically over-weighted, others radically under-weighted, and the system would tell us virtually nothing about what the wrongdoer did. ${ }^{72}$

Lying behind this reductio is the simple but significant point that official judgments as to criminal responsibility matter over and above the quantum of punishment that follows. Of course, punishment itself needs to be justified, and, in the individual case, is most plausibly located in, and limited by, the defendant's desert. ${ }^{73}$ But, additionally, judgments as to criminal responsibility should accurately reflect a participant's moral culpability and, in doing so, accurately reflect morally significant differences in culpability amongst participants. Variations in sentencing at best mitigate the principled concerns of abolishing complicity from legal responsibility.

The principled concern that the criminal law accurately captures the moral culpability of offenders underlies the embrace by many legal systems of a differentiated model of participation in crime and their related adoption of a normative model of principalship. ${ }^{74}$ A differentiated model of participation distinguishes among participants in crime in the attribution of responsibility. ${ }^{75}$ In contrast to a naturalistic model, a normative model of principalship builds normative considerations into the theory of agency, which often leads to the capture of those who control the commission of the crime within principalship. ${ }^{76}$ Both a differentiated model of participation and a normative model of principalship attempt to capture morally significant differences in culpability in the criminal law.

\subsection{Responsibility in International Criminal Law Specifically}

Up to this point, the argument has shown that Stewart remains trapped in the dilemma: he would claim that he, rather than his helpers, is responsible for his own article but that those who help others to commit international crimes are responsible for those crimes. Section 3.1 argued that no escape lies in a distinction between virtuous and wrongful acts; in both cases, principals remain morally responsible for their actions and accomplices for their contributions to the principal's

\footnotetext{
${ }^{70}$ Ohlin, supra note 3.

71 Ibid.

${ }^{72}$ Ibid. See also J. Horder, 'Rethinking Non-Fatal Offences against the Person', (1994) 14 OJLS 335,339 discussing the opposite perils of particularism and moral vacuity.

${ }^{73}$ See H.L.A. Hart, Punishment and Responsibility: Essays in the Philosophy of Law (1968); A. von Hirsch and A. Ashworth, Proportionate Sentencing: Exploring the Principles (2005).

${ }^{74}$ See e.g. the German approach in StGB $\S 25 ;$ StGB $\S 26 ;$ StGB $\S 27$. To be sure, a differentiated model of participation does not necessitate a normative model of principalship. See further N. Jain, Perpetrators and Accessories in International Criminal Law (2014).

${ }^{75}$ A. Eser, 'Individual Criminal Responsibility' in A. Cassese et al. (eds.), The Rome Statute of the International Criminal Court: A Commentary-Vol 1 (2002), 767 at 782.

${ }^{76}$ Van Sliedregt, supra note 9, at 71-2. See also Roxin, supra note 6; J. Vogel, 'How to Determine Individual Criminal Responsibility in Systemic Contexts: Twelve Models’ (2002) Cahiers de Défense Sociale 151.
} 
actions. Section 3.2 argued that the jump from moral responsibility to legal responsibility likewise provides no escape. The suggested practical and expressive benefits of a unitary model are not fully supported and, even if there were some small benefit, it should not override the fundamental principles of culpability and fair labelling that underpin a differentiated model of participation in crime. This section assesses a third and final argument that might allow an escape from the dilemma. This is the idea that the collectivity of international crimes specifically renders a differentiated model of perpetration inappropriate for the purpose of assigning responsibility.

There is a rich and prodigious literature on the collectivity of international criminality. ${ }^{77}$ As to the scale of the wrongdoing, genocide requires intent to destroy a protected group, in whole or in part; crimes against humanity are defined by a widespread and systematic attack on a civilian population. ${ }^{78}$ International crimes are often committed in an organizational context, with different participants playing different institutional roles. Even outside of the organizational context, central cases of mass atrocity often involve the collaboration among numerous actors plans are made, orders are given, victims are identified, and only then does the killing begin. ${ }^{79}$

The literature on the collective nature of international criminality gives rise to two fundamental questions. The first is an existential challenge to international criminal justice - should individual trials, which by their nature demand liberal standards of procedural and substantive fairness, play a central role in responses to mass atrocity? The second asks how modes of liability in international criminal law might capture systemic criminality without drifting into illiberal standards of collective guilt.

As to the first question, there is no doubt that international criminal trials ought not to be the only or even central response to mass atrocity. Within the criminal law, local approaches will in many cases be preferable. ${ }^{80}$ In international law and relations, the ordinary remedies in the law of state responsibility as well as unilateral and multilateral political responses will be important. ${ }^{81}$ Beyond that, depending on the local context, a range of measures in transitional justice, including lustration, disarmament, demobilization and reintegration, memorialization, truth commissions, and institutional and economic reform, ought to be a part of the conversation. ${ }^{82}$ To hold an individual criminally responsible is not to deny that that individual acted in a particular social and institutional context.

\footnotetext{
${ }^{77}$ See e.g. Osiel, supra note 14; M. Drumbl, Atrocity, Punishment and International Law (2007).

${ }^{78}$ See e.g. Art. 1 Convention on the Prevention and Punishment of the Crime of Genocide Convention (adopted 9 December 1948, entered into force 12 January 1951) 78 UNTS 277; Art. 7 Rome Statute, supra note 12.

${ }^{79}$ See Jackson, supra note 2, at 17.

${ }^{80}$ See P. Clark, The Gacaca Courts, Post-Genocide Justice and Reconciliation in Rwanda: Justice without Lawyers (2010); W. Burke-White, 'Proactive Complementarity: The International Criminal Court and National Courts in the Rome System of International Justice’, (2008) 49 Harvard International Law Journal 53.

${ }^{81}$ A. Nollkaemper, 'Systemic Effects of International Responsibility for International Crimes', (2010) 8 Santa Clara Journal of International Law 313. See also A. Nollkaemper and H. van der Wilt (eds.), System Criminality in International Law (2009).

${ }^{82}$ See generally R. Teitel, Transitional Justice (2000); N. Letki, 'Lustration and Democratisation in East-Central Europe', (2002) 54 East-Asia Studies 542; P. Hayner, Unspeakable Truths: Transitional Justice and the Challenge of Truth Commissions (2010); K. Theidon, 'Transitional Subjects: The Disarmament, Demobilization and Reintegration of Former Combatants in Colombia', (2007) 1 International Journal of Transitional Justice 66.
} 
As to the second question, which concerns the ability of modes of liability to properly account for the collectivity of international crimes, there is no doubt that a robust conception of coperpetration in international criminal law is required. ${ }^{83}$ At least some international crimes will be paradigmatic examples of wrongs committed by a group of individuals acting in concert. Many others will involve tightly constrained hierarchical structures. Attempts in the case law and scholarship to define categories of commission, co-perpetration, indirect perpetration, indirect co-perpetration, and joint criminal enterprise are a response to this basic insight about the collectivity of international crimes. ${ }^{84}$

Of course, the role of accomplice liability will shift according to the boundaries of principalship. A capacious doctrine of principalship may draw into its ambit participants who would ordinarily be thought of as aiders or abettors. Ohlin has argued that joint criminal enterprise, as articulated by the ad hoc tribunals, inculpates minor participants as principals in violation of the principle of culpability. ${ }^{85}$ Although its elements remain contested, the normative model of perpetration adopted by the International Criminal Court may well be a significant advance on the flaws of joint criminal enterprise. ${ }^{86}$ The requirement of control over the crime ties the responsibility of the perpetrator to her rational agency.

The key point here is that it does not follow from the phenomenological claim that international crimes paradigmatically involve multiple actors that responsibility ought necessarily to be either collective or unitary at the stage of attribution. The contributions of those multiple actors will likely vary in kind and gravity. ${ }^{87}$ Moreover, even assuming a normative model of principalship, there remains a morally significant distinction between those who control the commission of the crime and those who provide assistance to the individual or joint perpetrators. The principle of culpability - that criminal responsibility be tied to the defendant's own participation in the crime - is no less applicable here than in respect of a simple municipal crime. ${ }^{88}$

This point may be illustrated by reference to the well-known case of Dutch businessman, Frans van Anraat. In the 1980s, van Anraat sold more than 1100 tons of the chemical Thiodiglycol to the regime of Saddam Hussein. The chemical, which is used to produce mustard gas, was

\footnotetext{
${ }^{83}$ See N. Jain, 'Individual Responsibility for Mass Atrocity: In Search of a Concept of Perpetration', (2013) 61 American Journal of Comparative Law 831.

${ }^{84}$ See generally A. Danner and J. Martinez, 'Guilty Associations: Joint Criminal Enterprise, Command

Responsibility, and the Development of International Criminal Law', (2005) 93 California Law Review 82; J. Ohlin, 'Joint Intentions to Commit International Crimes', (2011) 11 Chicago Journal of International Law 693; N. Jain, Perpetrators and Accessories in International Criminal Law: Individual Modes of Responsibility for International Crimes (2014); J. Gadirov, 'Collective Intentions and Individual Criminal Responsibility in International Criminal Law' in Van Sliedregt and Vasiliev, supra note 2, at 342.

${ }^{85}$ J. Ohlin, 'The Co-Perpetrator Model of Joint Criminal Enterprise', in A. Klip and G. Sluiter (eds.), Annotated Leading Cases of International Criminal Tribunals: The International Criminal Tribunal for the former Yugoslavia 2003 - Volume 14 (2008), 739 at 742-744.

${ }^{86}$ See Werle and Burghardt, supra note 2, at 315-18.

${ }^{87}$ See H. Vest, 'Problems of Participation - Unitarian, Differentiated Approach, or Something Else', (2014) 12 JICJ 295 , at 302-3.

${ }^{88}$ See Werle and Burghardt, supra note 2, at 311 for an argument that the huge divergence in the responsibility of participants in international crimes makes it more important, rather than less important, for international criminal law to differentiate among participants compared to ordinary municipal criminal law.
} 
deployed in numerous attacks on Kurdish villages. ${ }^{89}$ On the basis of his knowledge that the chemical would be used in the attacks, Van Anraat was convicted in the Netherlands of aiding and abetting war crimes. ${ }^{90}$

Van Anraat is a paradigmatic example of what it is to be an accomplice. There is no doubt that complex questions of principal responsibility arise in respect of the chemical attacks themselves; among the Iraqi pilots who dropped the bombs, military officials who ordered them to do so, and civilian superiors who decided the course of action. Moreover, there is little doubt that the chemical attacks involved a number of actors and were, in a sense, collective. But that collectivity does not mean that we should not hold van Anraat responsible for what he did: contribute as an accomplice to the wrongdoing of others. ${ }^{91}$

A properly differentiated model of responsibility in international criminal law also answers Stewart's culpability critique of complicity doctrine as it currently stands. As is well-known, doctrine generally insists that the mental element for aiding and abetting is knowledge. ${ }^{92}$ Leaving aside his epistemological claim that a standard of knowledge makes no sense because we cannot know what will happen in the future, Stewart's central critique of accomplice liability is that, in some instances, it leads to a mismatch between the fault required of the accomplice and the fault required of the principal. ${ }^{93}$ This predominantly occurs with specific intent crimes; where the principal perpetrator of genocide must act with the specific intent to destroy the target group, the accomplice need only act with knowledge of that specific intent. Stewart argues that the conviction of the accomplice of genocide in these circumstances violates the principle of culpability. $^{94}$

Notice, however, that this critique rests on the assumption that the accomplice to genocide is convicted of the principal crime. Stewart points out that this is how the ad hoc tribunals have generally proceeded. However, there is no reason that this would necessarily be so - a properly differentiated system of responsibility would distinguish among participants at the level of the attribution of responsibility and reflect participants' varied culpability at sentencing. ${ }^{95}$ Ideally, this is how modes of responsibility will develop in international criminal law. ${ }^{96}$

\footnotetext{
${ }^{89}$ Public Prosecutor v. van Anraat, District Court, The Hague, Case No. 09/751003-04, 23 December 2005.

90 Ibid.

${ }^{91}$ Ibid. See also Prosecutor v. van Anraat, Dutch Supreme Court, 30 June 2009, Case No. 07/10742, 30 June 2009; H. van der Wilt, 'Genocide, Complicity in Genocide and International v. Domestic Jurisdiction: Reflections on the van Anraat Case', (2006) 4 JICJ 239.

${ }^{92}$ See e.g. Zyklon B-Trial of Bruno Tesch and Two Others (8 March 1946) (1947) I LRTWC 93; The Jaluit Atoll Case (13 December 1945) (1947) 1 LRTWC 71, 73 (United States Military Commission, Marshall Islands); Mrkšić and Šljivančanin appeal judgment, supra note 23; Prosecutor v. Taylor, Judgement, SCSL-03-01-A, AC, SCSL, 26 September 2013. Cf. Art. 25(3)(c) Rome Statute, supra note 12; Prosecutor v. Perišić, Judgement, Case No. IT-0481-A, Appeals Chamber, ICTY, 28 February 2013.

${ }^{93}$ Stewart, supra note 1 , at 190-199.

94 Ibid., at 198.

${ }^{95}$ Van Sliedregt, supra note 9, at 70-72.

${ }^{96}$ In respect of the Rome Statute, see K. Ambos, 'The First Judgment of the International Criminal Court (Prosecutor v. Lubanga): A Comprehensive Analysis of the Legal Issues, (2012) 12 International Criminal Law Review 115; Werle and Burghardt, supra note 2; Vest, supra note 87.
} 
To be sure, if modes of responsibility were properly differentiated it would not mean that the appropriate fault requirement for accomplice liability is self-evident. ${ }^{97}$ This is not the place for a detailed assessment of the fault element for complicity in international criminal law and the differences between the customary standard and that prescribed by the Rome Statute. In short, there are good arguments that a standard of knowledge strikes an appropriate balance between over-inculpation of insufficiently blameworthy accomplices and under-inculpation of those whose complicity ought to be sanctioned. ${ }^{98}$ Nonetheless, however the fault element develops, the critical point is that the law differentiates between principles and accomplices in the attribution of responsibility.

\section{Conclusion}

Stewart is responsible for writing The End of Modes of Liability; his helpers are responsible for helping him. Subject to various qualifications discussed above, this framework of responsibility provides a basic insight into how modes of liability should be constructed in international criminal law. As to complicity specifically, the decision of the ICTY Appeals Chamber in Perišić and consequent controversy have brought renewed attention to the elements of aiding and abetting liability. ${ }^{99}$ No doubt there are difficult questions to be answered about its outer bounds, especially with respect the participation of remote contributors. ${ }^{100}$ Nonetheless, these doctrinal controversies ought to be resolved within a framework that recognizes, in the attribution of responsibility, significant differences in the roles of participants.

\footnotetext{
${ }^{97}$ See Smith, supra note 42, at 46: 'There is no natural or automatically ascertainable proper level of mental involvement or culpability; it is a normative issue of what mental states, bearing in mind the social circumstances and consequences and possibilities for control, ought to be taken as appropriate subjects of criminal sanctions.'

${ }^{98}$ See G. Werle, 'Individual Criminal Responsibility in Article 25 ICC Statute', (2007) 5 JICJ 953, at 969-70; Jackson, supra note 2, at 46-54.

${ }^{99}$ Perišić, supra note 92.

${ }^{100}$ See J. Stewart, 'The ICTY Loses its Way on Complicity_Part 2', Opinio Juris, 3 April 2013 available at http://opiniojuris.org/2013/04/03/guest-post-the-icty-loses-its-way-on-complicity-part-2/; M. Ventura, 'Farewell "Specific Direction": Aiding and Abetting War Crimes and Crimes against Humanity in Perišić, Taylor, Šainović et al., and US Alien Tort Statute Jurisprudence' in S. Casey-Maslen (ed.), The War Report: Armed Conflict in 2013 (2014), 510 .
} 